\title{
Resistant Protein Promotes Glucagon-like Peptide-1 Secretion by Controlling the Cecal Fermentation in Rats Fed High Amylose Corn Starch
}

\author{
Ryoko Shimada ${ }^{1,2, *}$, Junichi Matsumoto ${ }^{3}$, Mikiharu Doi ${ }^{3}$, Kiyoshi Ebihara ${ }^{2}$ \\ ${ }^{1}$ School of Human Science and Environment, University of Hyogo, Himeji, Japan \\ ${ }^{2}$ Faculty of Health Sciences, Osaka Aoyama University, Minoh, Japan \\ ${ }^{3}$ Marutomo Co. Ltd., Iyo, Japan
}

Email address:

shimada@shse.u-hyogo.ac.jp (R. Shimada),r-shimada@osaka-aoyama.ac.jp (R. Shimada)

${ }^{*}$ Corresponding author

\section{To cite this article:}

Ryoko Shimada, Junichi Matsumoto, Mikiharu Doi, Kiyoshi Ebihara. Resistant Protein Promotes Glucagon-like Peptide-1 Secretion by Controlling the Cecal Fermentation in Rats Fed High Amylose Corn Starch. Journal of Food and Nutrition Sciences.

Vol. 7, No. 6, 2019, pp. 79-86. doi: 10.11648/j.jfns.20190706.11

Received: October 8, 2019; Accepted: October 25, 2019; Published: October 31, 2019

\begin{abstract}
It was examined whether undigested protein, namely resistant protein, affects glucagon-like peptide-1 (GLP-1) secretion in rats fed high amylose corn starch (HACS). Rats were fed one of three experimental diets for $28 \mathrm{~d}$ : casein without HACS, casein with HACS or dashigara with HACS. Dashigara is produced from Katsuobushi (smoke-dried skipjack tuna) treated with microbial protease. The apparent digestibilities of casein and dashigara are $96.0 \%$ and $84.5 \%$, respectively. The amount of rat cecal butyric acid and propionic acid were as follows: the dashigara with HACS group > the casein with HACS group > the casein without HACS group. The dashigara with HACS group had significantly greater cecal butyric acid and lower cecal succinic acid than the casein with HACS group. The GLP-1 concentration in portal vein blood increased as the amount of butyric acid and propionic acid in the cecal contents increased. Denaturing gradient gel electrophoresis of PCR-amplified 16S rRNA gene fragments showed that the composition of cecal microbiota differed among the three groups. These results suggest that resistant protein contained in dashigara promotes GLP-1 secretion by controlling fermentation efficiency as well as the fermentation profile of HACS through the changes in cecal microbiota in rats fed HACS.
\end{abstract}

Keywords: Glucagon-Like Peptide-1, High Amylose Corn Starch, Resistant Protein, Short Chain Fatty Acids, Cecal Microbiota, Cecal Fermentation

\section{Introduction}

Katsuobushi is an essential ingredient in Japanese cuisine. It is processed by boiling slivered skipjack tuna, removing the bones and skins, smoking and drying the muscle parts, and then applying a fine mold to the surface. The most fundamental use of Katsuobushi is in dashi stock which forms the basis of many Japanese soups and sauces. Within the home, dashi is also prepared using a more traditional method of heating flakes of Katsuobushi in near-boiling water, and then straining off the liquid. The demand for instant dashi powder or granules (dashi-no-moto) has been rapidly increasing over recent years. During the manufacturing process, Dashi-no-moto is obtained by digesting Katsuobushi flakes with endoand exo-type microbial proteases. Katsuobushi flakes change to grounds called "dashigara" in which the taste components are lost. Dashigara contains protein that resists protease digestion, and is known as resistant protein.

High amylose corn starch (HACS), resistant starch type 2 , is resistant to amylase digestion in the small intestine and is passed to the large intestine, where it is fermented by microbiota, resulting in the production of short-chain fatty acids (SCFA: acetic, propionic and n-butyric acid) that stimulate the secretion of glucagon-like peptide 1 
(GLP-1) in rodents [1]. The amount and profile of SCFA produced by microbial fermentation of indigestible carbohydrate might be affected by other indigestible food ingredients passed to the large intestine [2, 3]. Undigested protein, namely resistant protein, can alter the amount and profile of SCFA in the cecal contents of rats fed HACS by changing the ratio of carbohydrate and nitrogen as fermentative substrates for microbiota in the cecum [4].

The aim of this study was to examine whether the microbial protease-undigested fraction of smoke-dried skipjack tuna (dashigara), namely resistant protein, modulates GLP-1 secretion by controlling cecal fermentation in rats fed HACS.

\section{Materials and Methods}

\subsection{Preparation of Dashigara}

Powdered Katsuobushi (520 g) was suspended in $2 \mathrm{~L}$ of distilled water before $52 \mathrm{~g}$ of endo-type protease and endoand exo-type protease mixture was added (Alcalase and Flavourzyme, Novoenzymes, Chiba, Japan). The solution was incubated at $52^{\circ} \mathrm{C}$ for $17 \mathrm{~h}$. The enzymatic reaction was stopped by heat inactivation at $85^{\circ} \mathrm{C}$ for $20 \mathrm{~min}$. The resulting solution was filtered through a two-sheet pile filter cloth (pore size $100 \mu \mathrm{m}$ : Lion Co., Ltd., Tokyo, Japan) before drying the residue at $80^{\circ} \mathrm{C}$ for $5 \mathrm{~h}$. The dried residue was defined as dashigara. The yield of dashigara from Katsuobushi was $42.3 \%$.

The composition of dashigara was $(\mathrm{g} / \mathrm{kg}): 738 \mathrm{~g}$ protein, $149 \mathrm{~g}$ lipids, $34 \mathrm{~g}$ ash, $33 \mathrm{~g}$ water and $46 \mathrm{~g}$ others. Protein content was determined using the Kieldahl method [5], using a nitrogen-to-protein conversion factor of 6.25 . Lipid content was determined using the AOAC Soxhlet method 991.36 [6]. The ash content was determined using the direct ignition method $\left(550^{\circ} \mathrm{C}\right.$ overnight $)$. The amount of moisture was determined as the loss in weight after drying at $105^{\circ} \mathrm{C}$ for $24 \mathrm{~h}$. The results are shown as the means of two observations. The concentrations of protein, lipids, ash and moisture in dashigara were analyzed in duplicate.

The amino acid composition of casein and dashigara (Table 1) were determined using an amino acid analyzer (model JLC-555/V, Japan Electron Optics Laboratory Co., Ltd. Tokyo, Japan). The fatty acid compositions of soybean oil and oil extracted from dashigara (Table 2) were determined using a gas chromatography (model GC-14B, Shimadzu, Kyoto, Japan) equipped with a 30 $\mathrm{m} \times 0.25 \mathrm{~mm}$ DB-WAX capillary column. The injector and detector temperatures were set at $200^{\circ} \mathrm{C}$ and $230^{\circ} \mathrm{C}$, respectively. The initial column temperature was $50^{\circ} \mathrm{C}$ and was increased to $230^{\circ} \mathrm{C}$ at a rate of $4^{\circ} \mathrm{C} / \mathrm{min}$. The final temperature was held for $10 \mathrm{~min}$. Column flow rate was $5.0 \mathrm{~mL} / \mathrm{min}$. Peak area was quantified using a Shimadzu CR501 integrator.
Table 1. Apparent digestibilities and amino acid compositions of casein and dashigara (Experiment 1).

\begin{tabular}{lll}
\hline & Casein & Dashigara \\
\cline { 2 - 3 } Apparent digestibility $^{\mathbf{1}}$ & $\mathbf{9 6 . 0}$ & $\mathbf{8 4 . 5}$ \\
\cline { 2 - 3 } & $\mathbf{g} / \mathbf{k g}$ & \\
\hline Amino acid composition & \\
\hline Tau & 0.0 & 0.3 \\
Asp & 57.7 & 75.2 \\
Thr & 35.3 & 28.1 \\
Ser & 50.8 & 21.9 \\
Glu & 203.8 & 104.4 \\
Pro & 87.6 & 22.7 \\
Gly & 16.2 & 35.2 \\
Ala & 24.9 & 44.8 \\
Val & 56.3 & 53.1 \\
Met & 25.9 & 11.6 \\
Cys & 2.1 & 8.6 \\
Ile & 39.3 & 40.7 \\
Leu & 74.8 & 65.2 \\
Tyr & 38.1 & 26.0 \\
Phe & 45.7 & 42.8 \\
His & 18.4 & 21.7 \\
Lys & 72.1 & 39.0 \\
Arg & 29.0 & 26.0 \\
\hline
\end{tabular}

${ }^{1}$ Rats were randomly divided into two groups $(n=6)$, and allowed free access to the casein diet or dashigara diet for $14 \mathrm{~d}$. Feces were collected over the last $3 \mathrm{~d}$ of the experimental period. The following equation was used to determine the apparent digestibility of dietary protein $(\mathrm{D})$ : $\mathrm{D}=(\mathrm{I}-\mathrm{F}) \times 100 / \mathrm{I}$, where $\mathrm{I}$ is nitrogen intake and $\mathrm{F}$ is fecal nitrogen. The level of nitrogen in the diet and feces was analyzed in duplicate using the Kjeldahl method [5].

\subsection{Animals and Diets}

This study was approved by the Laboratory Animal Care Committee of Osaka-Aoyama University (\#17-29, \#17-30).

Rats were maintained in accordance with the Guidelines for the Care and Use of Laboratory Animals of Osaka-Aoyama University.

Male Wistar rats (Shizuoka Laboratory Animal Center, Shizuoka, Japan), at 7 weeks old, were used throughout this study. The rats were housed individually in screen-bottomed, stainless steel cages in a room maintained at $23 \pm 1^{\circ} \mathrm{C}$ with a 12 h light: dark cycle (light on, 0700-1900 h). The compositions of test diets used in this study are shown in Table 3 [7]. Gelatinized common corn starch (26\% amylose) and high-amylose corn starch (HACS, 68\% amylose) were donated by Matsutani Chemical Industry Co., Ltd. (Itami, Japan). The protein content of all test diets was adjusted to that of the casein diet. The rats were acclimated by feeding a commercial solid diet (Roden Lab Diet EQ, PMI, USA) for $7 \mathrm{~d}$.

\subsection{Experiment1: Measurement of the Apparent Digestibilities of Casein and Dashigara}

The apparent digestibilities of casein and dashigara were determined under isonitrogenous conditions. After acclimation, the rats were randomly divided into two groups $(n=6)$, and allowed free access to the casein diet or dashigara diet for $14 \mathrm{~d}$. Body weight and food intake were recorded daily for each rat in the morning before the food was replaced. Feces were collected over the last $3 \mathrm{~d}$ of the experimental period and were freeze-dried, weighed and 
milled. The concentrations of nitrogen $(\mathrm{N})$ in the diet and feces of each rat were analyzed in duplicate using the Kjeldahl method [5]. Rats were euthanized by decapitation. The following equation was used to determine the apparent digestibilities of casein and dashigara: Apparent digestibility $=($ nitrogen intake - fecal nitrogen $) /($ nitrogen intake $) \times 100$.

\subsection{Experiment 2: Effects of Dashigara on GLP-1 Concentration and the Profile of Cecal Short Chain Fatty Acid in Rats Fed High-amylose Corn Starch}

After acclimation, the rats were randomly divided into three groups $(n=6)$ : casein, casein + HACS and dashigara + HACS, and allowed free access to the casein, casein+HACS or dashigara+HACS diet, respectively, for $28 \mathrm{~d}$. Body weight and food intake were recorded daily for each rat in the morning before the food was replaced.

\subsubsection{Sampling and Analytical Procedures}

Before the rats were killed, feces were collected from each rat over the final $3 \mathrm{~d}$ of the experimental period; they were freeze-dried, weighed and milled.

At the end of the experiment, the rats were anesthetized with pentobarbital $(40 \mathrm{mg} / \mathrm{kg}$ body weight, Nembutal, Abbot Laboratories, North Chicago, IL, USA) $3 \mathrm{~h}$ after lights off. Portal vein blood was collected into cooled EDTA tubes containing aprotinin (NP-EA0205, NIPRO, Osaka, Japan) and dipeptidyl peptidase-4 (DPP-4) inhibitor (EMD Millipore Co., Ltd. Germany) to measure plasma GLP-1 concentrations. Plasma was separated by centrifugation at $1400 \times \mathrm{g}$ at $4^{\circ} \mathrm{C}$ for $15 \mathrm{~min}$, and stored at $-80^{\circ} \mathrm{C}$ until analysis.

After blood collection, the cecum was then removed and weighed. The cecal contents were then transferred into pre-weighed tubes and homogenized under $\mathrm{CO}_{2}$ gas. The cecal wall was flushed clean with ice-cold saline, blotted dry on filter paper, and weighed. Rats were euthanized by bleeding from the abdominal aorta.

Table 2. Composition of fatty acids in soybean oil and fat extracted from dashigara.

\begin{tabular}{llll}
\hline & & Oil & \\
\cline { 3 - 4 } Common name & Shorthand & Soybean Oil & $\begin{array}{l}\text { Oil extracted } \\
\text { from dashigara }\end{array}$ \\
\cline { 3 - 4 } & & \% & \\
\hline Saturated fatty acids & & & \\
Myristic acid & $14: 0$ & ND & 3.5 \\
Pentadecanoic acid & $15: 0$ & ND & 1.3 \\
Palmitic acid & $16: 0$ & 10.6 & 28.5 \\
Margaric acid & $17: 0$ & ND & 2.1 \\
Stearic acid & $18: 0$ & 3.9 & 9.8 \\
Monounsaturated fatty acids & & \\
Palmitoleic acid & $16: 1 \mathrm{n}-7$ & ND & 5.5 \\
Heptadecenoic acid & $17: 1$ & ND & 0.7 \\
Oleic acid & $18: 1 \mathrm{n}-9$ & 24.1 & 13.8 \\
Polyunsaturated fatty & acids & & \\
Linoleic acid & $18: 2 \mathrm{n}-6$ & 53.4 & 2.1 \\
Linolenic acid & $18: 3 \mathrm{n}-3$ & 6.8 & ND \\
Mead acid & $20: 3 \mathrm{n}-9$ & ND & 0.7 \\
Arachidonic acid & $20: 4 \mathrm{n}-6$ & ND & 1.8 \\
Icosapentenoic acid & $20: 5 \mathrm{n}-3$ & 0.2 & 4.1 \\
Docosapentaenoic & $22: 5$ & ND & 1.0 \\
\hline
\end{tabular}

\begin{tabular}{llll}
\hline & & Oil \\
\cline { 3 - 4 } Common name & Shorthand & Soybean Oil & $\begin{array}{l}\text { Oil extracted } \\
\text { from dashigara }\end{array}$ \\
\cline { 3 - 4 } & & $\%$ & \\
\cline { 3 - 4 } & & & \\
acid & Nocosahexaenoic & $22: 6 \mathrm{n}-3$ & 19.3 \\
$\begin{array}{l}\text { acid } \\
\text { Others }\end{array}$ & & 1.0 & 5.8 \\
\hline
\end{tabular}

Fatty acid composition analyses of soybean oil and oil extracted from dashigara were performed in duplicate using capillary gas chromatography. Fatty acid composition is presented as the percentage share of each individual fatty acid in the total pool of all fatty acids (\%). ND: not detected.

\subsubsection{Plasma Glucose, Insulin and Active Glucagon-like Peptide-1 Concentration}

GLP-1 concentration in portal vein plasma was measured using a commercially available ELISA kit (Linco Research, Millipore, St. Charles, MO, USA). Plasma glucose concentration was measured spectrophotometrically using a commercially available kit (Glucose CII Test Wako, Wako Pure Chemical Industry, Osaka, Japan). Plasma insulin concentration was measured using the sandwich ELISA method (Rat Insulin Kit, Morinaga Institute of Biological Science, Yokohama, Japan).

\subsection{3. pH, Water Content and Short Chain Fatty Acids in the Cecal Contents}

The water content of the cecal contents was determined as the difference between the wet and dry mass of the cecum after freeze-drying. The $\mathrm{pH}$ of the cecal contents was measured immediately after removal using a compact $\mathrm{pH}$ meter and a sampling sheet (Model C-1, Horiba, Tokyo, Japan) calibrated at $20^{\circ} \mathrm{C}$. SCFA (acetic, propionic, and n-butyric acid) in the cecal contents were measured using the internal standard method and HPLC (LC-6A, Shimadzu, Kyoto, Japan) equipped with a Shim-pack SCR-102H column $(8 \mathrm{~mm}$ i. d. $\times 30 \mathrm{~cm}$ long, Shimadzu) with an electroconductivity detector (CDD-6A, Shimadzu) [8].

\subsubsection{Profile Analysis of Cecal Microbiota by PCR-denaturing Gradient Gel Electrophoresis}

DNA was extracted from the cecal contents using a fecal DNA isolation kit (ISOFECAL for Beads Beating, Nippon Gene Co., Ltd. Tokyo, Japan) according to the manufacturer's instructions. DNA samples were used as a template to amplify the fragments of the $16 \mathrm{~S}$ rRNA gene with the universal primers HDA1-GC (5'-CGC CCG GGG CGC GCC CCG GGC GGG GCG GGG GCA CGG GGG GAC TCC TAC GGG AGG CAG T-3'; the GC clamp is in boldface) and HDA2 (5'-GTA TTA CCG CGG CTG GCA C-3') [9]. PCR and denaturing-gradient gel electrophoresis (DGGE) using the DCode universal mutation detection system (Bio-Rad) were performed as described by Walter et al. [9]. DGGE profiles were compared with Quantity One version 4.6.0 software (Bio-Rad, Hercules, CA, USA), and similarities were expressed with Dice's similarity coefficient.

\subsection{Statistical Analyses}

Data were expressed as means \pm SEM. Statistical analyses 
were performed using StatView 5.0 software (SAS Institute). Data were analyzed by one-way ANOVA, and significant differences among means were determined by the Tukey-Kramer test. Variance homogeneity was examined with the Bartlett test. When variances were not homogeneous, the data were analyzed by Kruskal-Wallis ANOVA and followed by a Steel-Dwass test. Linear regression analyses were performed using the Excel Statistics software, version 6.0 (Esumi Co., Ltd., Tokyo, Japan). Statistical significance was accepted at $\mathrm{p}<0.05$.

Table 3. Composition of the experimental diets ${ }^{1}$.

\begin{tabular}{|c|c|c|c|c|c|}
\hline \multirow{3}{*}{ Component } & \multicolumn{2}{|c|}{ Experiment 1} & \multicolumn{3}{|c|}{ Experiment 2} \\
\hline & Casein & Dashigara & Casein & Casein+HACS & Dashigara+HACS \\
\hline & \multicolumn{2}{|l|}{ g\% } & \multicolumn{3}{|l|}{ g\% } \\
\hline Protein & 17.8 & 17.8 & 17.8 & 17.8 & 17.8 \\
\hline Carbohydrate & 63.2 & 62.7 & 63.2 & 63.2 & 62.7 \\
\hline Fat & 7.0 & 7.0 & 7.0 & 7.0 & 7.0 \\
\hline Ingredient & \multicolumn{2}{|l|}{$\mathrm{g} / \mathrm{kg}$} & \multicolumn{3}{|l|}{$\mathrm{g} / \mathrm{kg}$} \\
\hline Casein $(\mathrm{CA})^{2}$ & 200.0 & 0.0 & 200.0 & 200.0 & 0.0 \\
\hline Gelatinized corn starch ${ }^{3}$ & 532.0 & 526.8 & 532.0 & 382.0 & 376.8 \\
\hline Sucrose & 100.0 & 100.0 & 100.0 & 100.0 & 100.0 \\
\hline Soybean oil & 70.0 & 34.1 & 70.0 & 70.0 & 34.1 \\
\hline Cellulose $\mathrm{e}^{4}$ & 50.0 & 50.0 & 50.0 & 50.0 & 50.0 \\
\hline Mineral Mix ${ }^{5}$ & 35.0 & 35.0 & 35.0 & 35.0 & 35.0 \\
\hline Vitamin $\mathrm{Mix}^{5,6}$ & 10.0 & 10.0 & 10.0 & 10.0 & 10.0 \\
\hline L-cystine & 3.0 & 3.0 & 3.0 & 3.0 & 3.0 \\
\hline High-amylose corn starch (HACS) ${ }^{7}$ & 0.0 & 0.0 & 0.0 & 150.0 & 150.0 \\
\hline Microbial protease-undigested fraction of smoke-dried bonito (Dashigara) ${ }^{8}$ & 0.0 & 241.1 & 0.0 & 0.0 & 241.1 \\
\hline
\end{tabular}

${ }^{1}$ The protein content of all test diets was adjusted to that of the casein diet.

${ }^{2}$ Acid-precipitated lactic casein, 30 mesh (New Zealand Dairy Board, Willington, New Zealand). The amount of nitrogen-to-protein conversion factor of 6.25.

${ }^{3}$ Gelatinized corn starch (Matsunorin-CM, 26\% amylose) was provided by Matsutani Chemical Industry Co., Ltd. (Itami, Japan).

${ }^{4}$ Cellulose powder, PC200 (Danisco Japan Ltd, Tokyo, Japan)

${ }^{5}$ Mineral and Vitamin Mix - Based on AIN-93G vitamin and mineral mixes [7] (Oriental Yeast Co., Ltd. Tokyo, Japan)

${ }^{6}$ The vitamin mix contained $2.5 \mathrm{~g}$ choline bitartrate per $10 \mathrm{~g}$.

${ }^{7}$ High-amylose corn starch (HA-7, 68\% amylose), provided by Matsutani Chemical Industry Co., Ltd. (Itami, Japan).

${ }^{8}$ The amount of protein and fat in dashigara was $738 \mathrm{~g} / \mathrm{kg}$ and $149 \mathrm{~g} / \mathrm{kg}$, respectively. Protein content was determined by the Kieldahl method [5], using a nitrogen-to-protein conversion factor of 6.25. Lipid content was determined using the AOAC Soxhlet method 991.36 [6].

\section{Results}

\subsection{Apparent Digestibilities of Casein and Dashigara}

The apparent digestibilities of casein and dashigara were 96.0 and $84.5 \%$, respectively (Table 1 ).

\subsection{Body Weight Gain, and Food Intake, Blood Glucose and Insulin}

Body weight gain and food intake were not affected by the diets (Table 4). The concentrations of glucose and insulin in abdominal aorta plasma were not affected by the diets.

\subsection{Glucagon-like Peptide-1 Concentration in Portal Vein Blood}

The GLP-1 concentration in portal vein blood was significantly higher in the casein+HACS group compared with the casein group, and the concentration was significantly lower in the casein+HACS group compared with the dashigara+HACS group (Table 4). The GLP-1 concentration in portal vein blood significantly correlated with the amount of total SCFAs $(r=0.999, \mathrm{P}=0.002)$ and propionic acid $(\mathrm{r}=0.995, \mathrm{P}=0.023)$ in the cecal contents.

\subsection{Wet Weight and pH Value of the Cecal Contents}

The wet weight of the cecal contents did not significantly differ between the casein+HACS group and the casein group, but was significantly heavier in the dashigara+HACS group compared with the casein and casein+HACS groups (Table 4). The moisture content of the cecal contents was not affected by diet. The $\mathrm{pH}$ value of the cecal contents was significantly lower in the casein+HACS group compared with both the casein group and dashigara+HACS group, which also differed $(\mathrm{P}<0.05)$ from each other.

Table 4. Body weight gain, food intake, portal vein plasma GLP-1 concentration, and wet weight, moisture, pH, short chain fatty acids in the cecal contents, and fecal output in rats fed either the casein, casein + HACS or dashigara +HACS diet.

\begin{tabular}{llll}
\hline & Casein & Casein+HACS & Dashigara+HACS \\
\hline Body weight gain, g/28 d & $94 \pm 2$ & $90 \pm 7$ & $99 \pm 2$ \\
Food intake, g/28 d & $449 \pm 6$ & $456 \pm 13$ & $446 \pm 7$ \\
Abdominal aorta plasma & & & $12.6 \pm 0.7$ \\
Glucose, mmol/L & $12.9 \pm 0.5$ & $5.69 \pm 0.51$ & $6.39 \pm 0.79$ \\
Insulin, ng/mL & $6.04 \pm 0.52$ & & \\
Portal vein plasma & & & \\
\hline
\end{tabular}




\begin{tabular}{llll}
\hline & Casein & Casein+HACS & Dashigara+HACS \\
\hline GLP-1, pmol/L & $9.85 \pm 0.25^{\mathrm{a}}$ & $35.65 \pm 3.36^{\mathrm{b}}$ & $48.36 \pm 3.21^{\mathrm{c}}$ \\
Cecal content & $1.42 \pm 0.02^{\mathrm{a}}$ & $1.68 \pm 0.11^{\mathrm{a}}$ & $2.39 \pm 0.11^{\mathrm{b}}$ \\
Wet weight, g & $21.3 \pm 2.8$ & $25.4 \pm 4.3$ & $23.4 \pm 1.7$ \\
Moisture, \% & $7.86 \pm 0.02^{\mathrm{c}}$ & $6.59 \pm 0.06^{\mathrm{a}}$ & $7.37 \pm 0.03^{\mathrm{b}}$ \\
$\mathrm{pH}$ & & & \\
Organic acids, mmol/cecum & & & $360.7 \pm 23.8^{\mathrm{b}}$ \\
Short chain fatty acid & $46.1 \pm 2.4^{\mathrm{a}}$ & $311.9 \pm 22.8^{\mathrm{b}}$ & $125.4 \pm 12.3^{\mathrm{c}}$ \\
Acetic acid & $18.4 \pm 0.6^{\mathrm{a}}$ & $86.7 \pm 9.8^{\mathrm{b}}$ & $133.9 \pm 13.0^{\mathrm{c}}$ \\
Propionic acid & $14.0 \pm 1.2^{\mathrm{a}}$ & $38.6 \pm 1.7^{\mathrm{b}}$ & $619.8 \pm 16.8^{\mathrm{c}}$ \\
n-Butyric acid & $75.5 \pm 1.5^{\mathrm{a}}$ & $438.5 \pm 11.9^{\mathrm{b}}$ & $33.5 \pm 5.7^{\mathrm{b}}$ \\
Total* & $1.7 \pm 0.3^{\mathrm{a}}$ & $345.7 \pm 66.9^{\mathrm{c}}$ & \\
Succinic acid & & & $2.39 \pm 0.11^{\mathrm{b}}$ \\
Fecal output & $1.42 \pm 0.02^{\mathrm{a}}$ & $1.68 \pm 0.11^{\mathrm{a}}$ & $1.83 \pm 0.14^{\mathrm{b}}$ \\
Wet weight, g/day & $1.11 \pm 0.10^{\mathrm{a}}$ & $1.23 \pm 0.06^{\mathrm{a}}$ & $23.8 \pm 2.7^{\mathrm{c}}$ \\
Dry weight, g/day & $8.6 \pm 2.3^{\mathrm{a}}$ & $16.4 \pm 1.5^{\mathrm{b}}$ & \\
Bile acids, $\mu$ mol/day & & & \\
\hline
\end{tabular}

Data are presented as the mean $\pm S E M ; n=6$. Mean values in each row with different superscript letters are significantly different $(\mathrm{P}<0.05)$. Means values in each row without superscript letters are not significantly different $(\mathrm{p}>0.05)$. The data were analyzed using one-way ANOVA followed by the Tukey-Kramer test to evaluate comparisons a mong groups. ${ }^{*}$ Total $=$ Acetic acid + Propionic acid + n-Butyric acid

\subsection{Amounts and Profile of Short Chain Fatty Acid in the \\ Cecal Contents}

The amounts of acetic acid in the cecal contents were significantly greater in the casein+HACS and dashigara + HACS groups compared with the casein group (Table 4). The amount of propionic acid and n-butyric acid in the cecal contents were in the cecal contents was significantly greater in the casein+HACS group compared with the casein group, but the amount was significantly smaller in the casein+HACS group compared with the dashigara+HACS group. The amount of succinic acid in the cecal contents was significantly greater in the casein+HACS group compared with the casein group, but the amount was significantly smaller in the dashigara+HACS group compared with the casein+HACS group.

\subsection{Fecal Weights and Amounts of Bile Acid in Feces}

The wet and dry weights of feces were significantly higher in the dashigara+HACS group compared with the casein and casein+HACS groups (Table 4). The amount of bile acids which were excreted via the feces was as follows: the dashigara+HACS group $>$ the casein + HACS group $>$ the casein group.

\subsection{PCR-denaturing Gradient Gel Electrophoresis Analysis of the Cecal Contents}

The 16S rRNA gene profiles of the microbial collections in the cecal samples were generated by PCR coupled with DGGE (Figure 1A). The dendrogram had a clustering pattern with three visibly distinct clusters, suggesting the microbiota in cecal contents was modulated by feeding HACS and dashigara (Figure 1B).

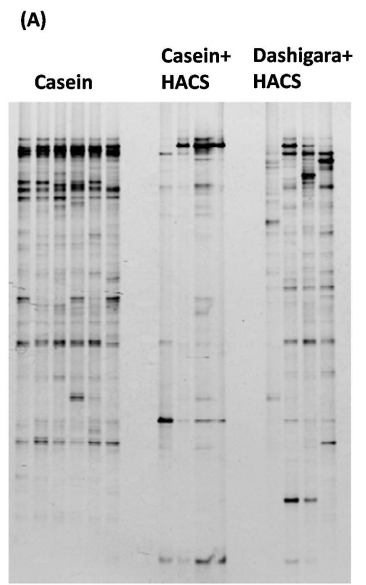

(B)

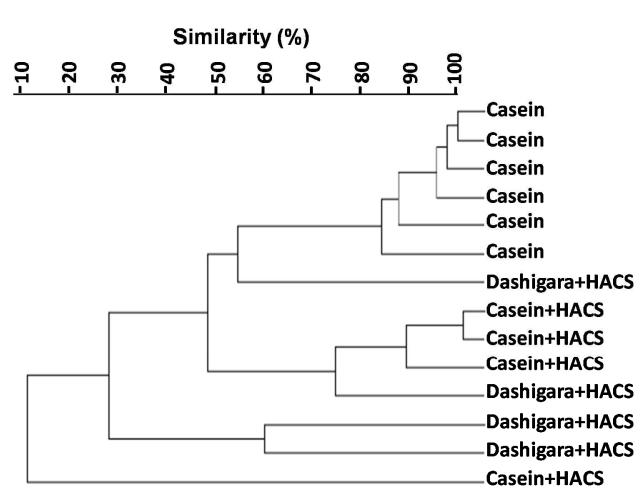

Figure 1. PCR-denaturing gradient gel electrophoresis (DGGE) analysis of cecal microbiota based on 16S rRNA gene sequences in rats fed one of three different diets for 4 weeks: the casein diet, casein $+H A C S$ diet or dashigara+HACS diet. Dashigara is an undigested fraction after treating Katsuobushi (smoke-dried skipjack tuna) with microbial protease.

(A) SYBR green staining of PCR products separated by DGGE. (B) Similarities among DGGE band profiles of cecal bacteria of rats were calculated based on the position and intensity of bands, and the dendrogram of DGGE band profiles was constructed by the unweighted pair-group method with arithmetic mean (UPGMA) clustering method. Distances are measured in arbitrary units. 


\section{Discussion}

This study examined whether resistant protein affects blood GLP-1 concentration and SCFA profile by controlling the cecum fermentation in rats fed HACS. Dashigara was used as a resistant protein source. Dashigara was produced by drying at $80^{\circ} \mathrm{C}$ for $5 \mathrm{~h}$ after digesting Katsuobushi flake with microbial. The main components of dashigara are proteins and lipids. The apparent protein digestibility was lower in dashigara when compared with casein; this may be due to the preparing process that involves complex chemical reactions, such as protein-protein interactions and protein-fat reactions. These reactions would have occurred especially in the drying process preparing dashigara, which would bring the lower apparent digestibility of dashigara. Generally, the main end products of microbial fermentation of indigestible carbohydrate such as dietary fiber and resistant starch are SCFA such as acetic, propionic and n-butyric acids. The primary site of SCFA production in rats is the cecum. In this study, HACS ingestion increased the amount of SCFA in the cecal contents. The addition of dashigara to the diet further increased the amount of SCFA in the cecal contents. Shimada et al. previously reported that rats fed resistant starch showed an increase in GLP-1 secretion in lower gut through increase SCFA production [10]. In this study, the concentration of GLP-1 in portal vein blood and total amount of SCFA in the cecal contents were increased in rats fed a diet containing HACS: the concentration of GLP-1 in portal vein blood increased as the amount of total SCFA in the cecal contents increased. This was consistent with the result of our previous study in rats fed 10 kinds of dietary fiber with different properties [10].

SCFA stimulate GLP-1 secretion from L cells by stimulating the free fatty acid receptor 2 (FFAR2/GPR43) and the free fatty acid receptor 3 (FFAR3/GPR41) [11, 12]. FFAR3 is predominantly expressed in small intestine $\mathrm{L}$ cells whereas FFAR2 is predominantly expressed in colonic $\mathrm{L}$ cells [11]. A previous study showed that FFAR2 more activated by acetate and propionate than butyrate [13]. In this study, the amounts of propionic acid and butyric acid in the cecal contents were as followed: the dashigara+HACS group $>$ the casein + HACS group $>$ the casein group. Of the SCFA produced by colonic fermentation of available carbohydrates, propionate has been shown to have the highest affinity for FFAR2 [14]. Intra-colonic administration of propionate stimulates the concurrent release of GLP-1 in rats and mice [15]. In this study, the concentration of GLP-1 in portal vein blood increased with the increase in propionic acid and butyric acid in the cecal contents.

It has been reported that the amount of succinic acid in the cecal contents increased markedly in rats fed HACS with casein as the protein source, but the increase in succinic acid was decreased in rats fed HACS with potato protein containing resistant protein as the protein source, suggesting that the ratio of starch to nitrogen in the cecum controls the efficiency of fermentation as well as the profile of fermented products of HACS, possibly as a result of a change in microbial composition $[4,16]$. In this study, the amount of succinic acid in the cecal contents was significantly increased in rats fed the casein+HACS diet; however, there was a significant decrease in succinic acid in rats fed the dashigara+HACS diet compared with the casein+HACS diet.

The $\mathrm{pH}$ value of the cecal contents in rats fed the casein+HACS diet was significantly lower than the $\mathrm{pH}$ value in rats fed the dashigara+HACS diet. An influx of large amounts of easily fermented substrate such as HACS into the large intestine often leads to the accumulation of lactic and succinic acids [17]. Succinic acid is suggested likely to be slowly absorbed [17]; therefore, the lower $\mathrm{pH}$ value of the cecal contents in the casein+HACS group might be due to the accumulation of succinic acid. The luminal $\mathrm{pH}$ value imposes selective pressure on microbial growth and metabolism, and is an important determinant of the distribution of the major end products of fermentation.

The results of PCR-DGGE analyses suggested differences of microbial community composition in the cecal contents among the three groups, which could affect cecal fermentation.

Fecal bile acid excretion was greater in rats fed the dashigara+HACS diet compared with those fed the casein+HACS diet, suggesting that dashigara interrupted the enterohepatic circulation of bile acids. When the enterohepatic circulation of bile acids is interrupted, primary bile acids enter the large intestine in increased concentration, and those are then metabolized into secondary bile acids by intestinal microbiota. G-protein-coupled bile acid receptor 1 (GPBAR-1) mainly binds secondary bile acids and promotes secretion of GLP-1 [18, 19]. Bile acid sequestrants can bind bile acids, interrupting the enterohepatic circulation of bile acids; this may divert bile acids from the enterohepatic circulation, increasing their fecal excretion [20] and potentially enlarging the cecal bile acid pool, producing an elevated secondary/primary bile acid ratio. Bile acid sequestrants such as cholestyramine and colesevelam improved insulin resistance in diabetic rats by increasing GLP-1 secretion [21, 22]. Dashigara with resistant protein might interrupt the enterohepatic circulation of bile acids by acting as a bile acid sequestrant.

The fermented protein products include potentially toxic substances such as ammonia, phenols, thiols and indoles; suggesting that large intake of resistant protein might cause health problem. Therefore it would be better to avoid a large intake of resistant protein. The balance between carbohydrate and protein as fermentative substrates for microbiota in the large intestine would be a critical issue.

Dashigara contains two major components: proteins and lipids. The oil extracted from dashigara was rich in docosahexaenoic acid (DHA). Docosahexaenoic acid is an agonist of the free fatty acid receptor 4 (FFAR4/GPR120) in the lower ileum and large intestine [23], and a potent stimulator of GLP-1 secretion [24, 25]. DHA is the most potent FFAR4 agonist [26]. In addition to the resistant 
protein, DHA might be involved in the effect of dashigara to increase the concentration of GLP-1 in portal vein blood.

\section{Conclusion}

The rats fed HACS with resistant protein had significantly higher portal vein blood GLP-1 concentration and had significantly greater cecal total SCFA, n-butyric acid and propionic acid when compared with rats fed HACS without resistant protein. The results suggest that resistant protein promotes GLP-1 secretion by controlling the fermentation efficiency and the fermentation profile of HACS in the cecum, and supports our experimental hypothesis that resistant protein modulates GLP-1 secretion by controlling the cecal fermentation of HACS in the rats fed HACS. However, since dashigara contains DHA, an FFAR4 agonist, DHA may also be involved in the modulation in GLP-1 secretion in rats fed dashigara. The effects of resistant protein and DHA on the modulation in GLP-1 secretion should be examined individually. Since it is unclear how dashigara promote GLP-1 secretion, further studies are needed to clarify the mechanism.

\section{Acknowledgements}

The authors are grateful for funding support from The Science Research Promotion Fund (grand number \#24580187). The authors declare that they have no conflicts of interest.

\section{References}

[1] Lei Z, Ting LH, Li S, Chen FQ, Ling QL, Ping JW. Effect of dietary resistant starch on prevention and treatment of obesity-related diseases and its possible mechanisms. Biomed Environ Sci 2015; 28: 91-97.

[2] Duda-Chodak A, Tarko T, Satora P, Sroka P. Interaction of dietary compounds, especially polyphenols, with the intestinel microbeta: a review. Eur J Nutr 2015; 54: 325-341.

[3] Jha R, Berrocoso JFD. Dietary fiber and protein fermentation in the intestine of swine and their interactive effects on gut health and on the environment: A review. Anim Feed Sci Technol 2016; 212: 18-26.

[4] Morita T, Kasaoka S, Ohhashi A, Ikai M, Numasaki Y, Kiriyama S. Resistant proteins alter cecal short-chain fatty acid profiles in rats fed high-amylose cornstarch. J Nutr 1998; 128: $1156-64$.

[5] Miller L, Houghton JA. The micro-Kjeldahl determination of the nitrogen content of amino acids and protein. J Biol Chem 1945; 159: 373-383.

[6] AOAC (Association of Official Analytical Chemists) 1995. Official Methods of Analysis, 16th Edition. AOAC International, Gaitherburg, MD.

[7] Reeves PG, Nielsen FH, Fahey GC Jr. AIN-93 purified diets for laboratory rodents: final report of the American Institute of Nutrition ad hoc writing committee on the reformation of the
AIN-76A rodent diet. J Nutr 1993; 123: 1939-1951.

[8] Ebihara K, Shiraishi R, Okuma K. Hydroxypropyl-modified potato starch increases fecal bile acid excretion in rats. J Nutr 1998; 128: 848-854.

[9] Walter J, Tannock GW, Tilsala-Timisjarvi A, Rodtong S, Loach DM, Munro K, et al. Detection and indentification of gastrointestinal Lactobacillus species by using denatureing gradient gel electrophoresis and species-specific PCR primers. Appl Environ Microbiol 2000; 66: 297-303.

[10] Shimada R, Yoshimura M, Murakami K, Ebihara K. Plasma voncentrations of GLP-1 and PYY in rats fed dietary fiber depend on the fermentability of dietary fiber and respond to an altered diet. Int J Clin Nutr Diet 2015; 1: 103.

[11] Tolhurst G, Heffron H, Lam YS, Parker HE, Habib AM, Diakogiannaki E, et al. Short-chain fatty acids stimulate glucagon-like peptide-1 secretion via the G-protein-coupled receptor FFAR2. Diabetes 2012; 61: 364-371.

[12] Bolognini D, Tobin AB, Milligan G, Moss CE. The pharmacology and function of receptors for short-chain fatty acids. Mol Pharmacol 2016; 89: 388-398.

[13] Puddu A, Sanguineti R, Montecucco F, Viviani GL. Evidence for the gut microbiota short-chain fatty acids as key pathophysiological molecules improving diabetes. Mediat Inflamm Review article ( 9 pages), Article ID 162021, Volume 2014 (2014).

[14] Brown AJ, Goldsworthy SM, Barnes AA, Eilert MM, Tcheang L, Daniels D, et al. The orphan G protein-coupled receptors GPR4 and GPR43 are activated by propionate and other short chain fatty acids. J Biol Chem 2003; 278: 11312-11319.

[15] Psichas A, Sleeth ML, Murphy KG, Brooks L, Bewick GA, Hanyaloglu AC, et al. The short chain fatty acid propionate stimulates GLP-1 and PYY secretion via free fatty acid receptor 2 in rodent. Int J Obes (Lond) 2015; 39: 424-429.

[16] Macfarlane GT, Macfarlane S. Factors affecting fermentation reactions in the large bowel. Proc Nutr Soc 1993; 52: 367-373.

[17] Hoshi S, Sakata T, Mikuni K, Hashimoto H, Kimura S. Galactosylsucrose and xylosylfructoside alter digestive tract size and concentration of cecal organic acids in rats fed diets containing cholesterol and cholic acid. J Nutr 1994; 124: 52-60.

[18] Chiang JYL, Pathak P, Liu H, Donepudi A, Ferrell J, Boehme S. Intestinal farnesoid $X$ receptor and Takeda $G$ protein couple receptor 5 signaling in metabolic regulateon. Dig Dis 2017; 35: 241-245.

[19] Fiorucci S, Biagioli M, Zampella A, Distrutti E. Bile acids activated receptors regulate innate immunity. Front Immunol 2018 Aug 13; 9: 1853.

[20] Shapiro H, Kolodziejczyk AA, Halstuch D, Elinav E. Bile acids in glucose metabolism in health and disease. J Exp Med 2018; 215: 383-396.

[21] Chen L, McNulty J, Anderson D, Liu Y, Nystrom C, Bullard S, et al. Cholestyramine reverses hyperglycemia and enhances glucose-stimulated glucagon-like peptide 1 release in Zucker diabetic fatty rats. J Pharmacol Exp Ther. 2010; 334: 164-170.

[22] Harach T, Pols TW, Nomura M, Maida A, Watanabe M, Auwerx J, et al. TGR5 potentiates GLP-1 secretion in response to anionic exchange resins. Sci Rep 2012; 2: 430. 
[23] Zhang, D.; Leung, P. S. Potential roles of GPR120 and its agonists in the management of diabetes. Drug Des Dev Ther 2014; 8: 1013-1027.

[24] Wang X, Chan CB. n-3 polyunsaturated fatty acids and insulin secretion. 2015; J Endocrinol 244: R97-R106.

[25] Rossmeisl M, Macek JZ, Kuda O, Jelenik T, Medrikova D, Stankova B, et al. Metabolic effects of n-3 PUFA as phospholipids are superior to triglycerides in mice fed a high-fat diet: possible role of endocannabinoids. Plos One 7 (2012) e38834.

[26] Nohr MK, Pedersen MH, Gille A, Egerod KL, Engelstoft MS, Husted AS, et al. GPR41/FFAR3 and GPR43/FFAR2 as cosensors for short-chain fatty acids in enteroendocrine cells vs FFAR3 in enteric neurons and FFAR2 in enteric leukocytes. Endcrinology 2013; 154: 3552-3564. 